\title{
ボイド放電劣化における破壊予知
}

$\begin{array}{llllll}\text { 正員 } & \text { 伊 } & \text { 藤 } & \text { 真 } & \text { 澄 } & \text { (武蔵工大) } \\ \text { 正員 } & \text { 伊 } & \text { 藤 } & \text { 泰 } & \text { 郎 } & \text { (武蔵工大) } \\ \text { 正員 堺 } & & \text { 孝 } & \text { 夫 (武蔵工大) } \\ \text { 非会員 } & \text { 江 原 } & \text { 由 泰 (武藏工大) }\end{array}$

\section{Prediction of Breakdown by Void Discharge Aging}

Masumi Ito, Member, Tairo Ito, Member, Takao Sakai, Member, Yoshiyasu Ehara, Nonmember (Musashi Institute of Technology)

Recentry, the neccessity of establishing the way to diagnose the aging of insulation materials and to prediction of insulation breakdown become important.

In this paper, the prediction of breakdown is considered. A cylindlical void which is made of polyethylene is used for experiments. And the distribution of the discharge magnitude in relation to phase angle of applied voltage is measured by a partial discharge measuring system.

The discharge measurements, such as the discharge magnitude $Q$, number of pulses $N$, average discharge magnitude $Q_{A V}$, the skweness and the kurtosis are calculated from the distribution to estimate the time to breakdown. In the early stage of aging. life (time to breakdown) can be estimated by regression line which shows the relation between the life and the discharge measurement.

And the new parameters $G$ and $C$ are proposed for the prediction of breakdown and are examined their effectiveness for prevention. $G$-parameter is the center of gravity and $C$-parameter is the gradient of the discharge distrbution. They symbolize the portent of the breakdown. It is confirmed that these two parameters are efficient to predict the breakdown just before the breakdown occured.

キーワード：ボイド, 部分放電, 放電電荷分布, 破壞予知

\section{1. まえがき}

近年, 電力機器が大容量化, 高電圧化される一方, 絶縁材料は薄膜化, 軽量化が要求され, ポリエチレン などの高分子材料が絶縁材料として広く用いられてい る。高分子絶縁の高電圧下における絶縁劣化の大きな 原因の一つに，部分放電によるものがあり，特にボイ ドの存在下における部分放電劣化はその主因ともなり 得る。この問題に対してはこれまで多くの研究がなさ れ(1) (3)，様々な对策が講じられてきたが，これらの 対策も必ずしも万全であるとは言えない。絶縁組織中 では部分放電が発生しないことが望ましいが, 最近で はその発生が致命傷になるかどうかの判断が問題とさ
れてきている。すなわち, 部分放電の発生により短時 間に絶縁破壊に至るかどうかの判断が重要になり, 絶 緣破壊事故防止のための絶緑劣化診断法の確立が要請 されている。また，近年ではマイクロコンピュータの 発達に伴い，部分放電の測定にも利用されるようにな り, 測定データの分解能の向上や多量のデータを統計 的に処理することが可能となり, 絶縁劣化診断におい てもコンピュータ診断が主流となっている。特に, 最 近では部分放電の発生する印加電㾏の位相角に対する 解析も行われ(4), 劣化プロセス推定のためのデータが 蓄積されつつあり，今後の劣化診断のためのエキスパ ートシステムの構築へ多大なデータを供給することが 期待される。 
著者らは，これまで独自で開発した部分放電計測シ ステムにより，平行平板状ボイドまたは絶縁厚の厚い 材料の劣化末期に見られるトリーイング劣化の各プロ セスに対して印加電圧の位相角解析の有意性を確認し てきた ${ }^{(5)}$ 。しかし，これらの診断は定性的な判断を基 に行われ，また実験の再現性にも問題があった。そこ で本論文では劣化初期における実験データを蓄積し， それらを基に寿命推定を行い，更に破壊直前では破壞 の前兆を象徵する放電電荷分布の変化を特徵づけるパ ラメータを考案し, 破壊予知への有意性を検討した。 特にここでは，絶縁層が薄い試料について取扱つてお り，放電の局所化や群小化から，破壊までの期間が比 較的短い場合の検討を行った。

\section{2. 実験}

〈2・1〉試料および電極構成試料および電極構 成を図 1 に示す。材料は絶縁性能に優れ, 電力機器あ るいはケーブルなどに広く用いられているポリエチレ ンを使用した。試料は一辺 $10 \mathrm{~cm}$, 厚さ $1 \mathrm{~mm}$ の低密 度ポリエチレン板の中央に直径 $21 \mathrm{~mm}$ の孔開け, その両面に $\mathrm{P}_{2} \mathrm{O}_{5}$ の入ったデシケータ内で 24 時間以 上乾燥させた, 愿さ $50 \mu \mathrm{m} の \mathrm{PE}$ フィルム(昭和電 工製ショーレックス S 5008）をシリコーングリスに よって貼合せ，ボイド内が空気 1 気圧となる三枚重ね の円筒ボイドを有する模擬ボイドを作成した。比較的 大きなボイド径としたのは，赤外光の通路をできるだ け広くして精度を上げるためである。試料の両側に は, 500 メッシュ（大きさ $40 \times 40 \mathrm{~mm}$ 開口率 $68 \%$ ) を密着させて，これを電極とした。しかし，赤外線吸 収スペクトルによる劣化生成物の解析に関しては別途 報告する。

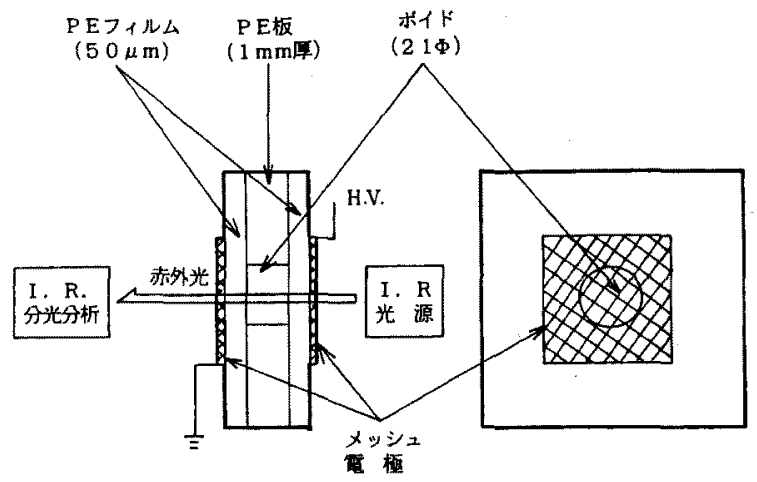

図 1 試料招よび電極構成

Fig. 1. Specimen and electrode configuration.
〈2・2〉実験方法 図 2 に実験システムを示す。 放電パルスの検出は $C-R$ 検出回路を用い, 部分放電 計測システムへ入力した。システムでは, 図 3 に示ず ように $50 \mathrm{~Hz}$ の印加電圧の負のピークから正のピー クまでの $10 \mathrm{~ms}$ の区間を九つの等しい領域 $(\phi 1, \phi 2$, $\cdots, \phi 9) に$ 分け，各々の領域で発生する放電パルスの 放電電荷と, 発生頻度を計測し, コンピュータに取込 み処理した。娜定した放電パルスは正パルスのみであ るが，図1の電極系は対称形であるので放電特性に対 する印加電圧の極性効果を無視して，半周期の計測で も放電特性の解析には十分である。実験は AC 50 $\mathrm{Hz}, 4.2 \mathrm{kV}$ を印加し, 放電電荷測定は電圧印加直後 から破壊に至るまで行った。放電電荷分布は図 4 のよ うな位相角別の $q-n-t$ 三次元データである。これを 計算処理し, 放電諸量として放電電荷 $Q$, パルス発 生頻度 $N$, 平均放電電荷 $Q_{A V}$ を求めた。またこの放 電諸量の表示方式を換え，位相角特性として $\phi-Q-t$, $\phi-N-t, \phi-Q_{A V}-t$, 表示した。図 $5 k \phi-Q-t$ 特性の 一例を示す。更に位相角特性の分布形状を特徵づける パラメータとして岡本らの提案した ${ }^{(6)}$ 分布のひずみ度 $S$, とがり度 $K$ を求めた。代表的な分布のひずみ度 $S$ ，とがり度Kを図 6 に示す。ひずみ度 $S$ は分布の 対称性を表すパラメータであり, 分布の形状が右上り

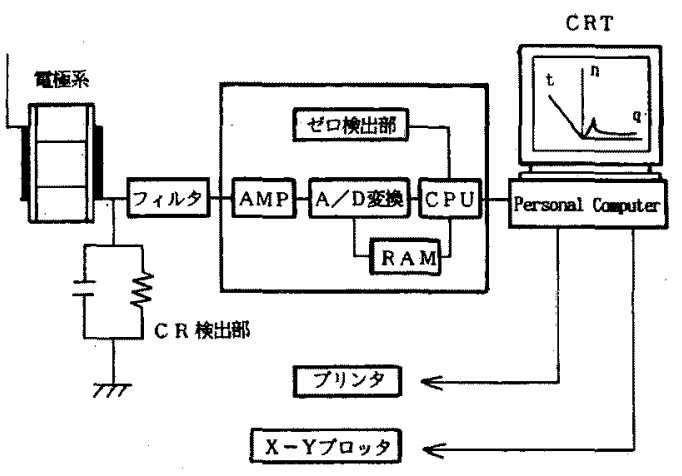

図 2 部分放電計測システム

Fig. 2. Partial discharge pulse measurment system

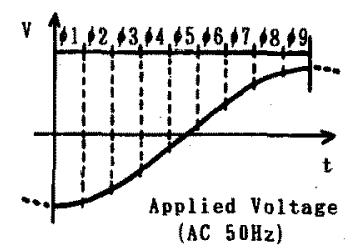

図 3 位相角区間

Fig. 3. Phase angle window

T. IEE Japan, Vol. 110-A, No. 11, '90 


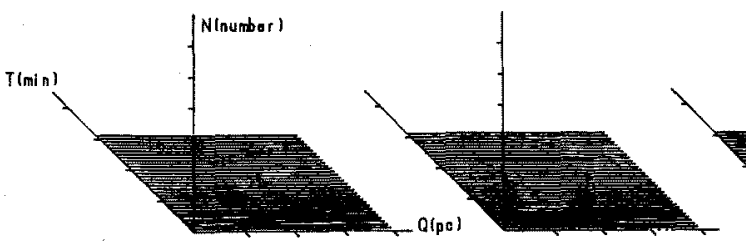

(1)

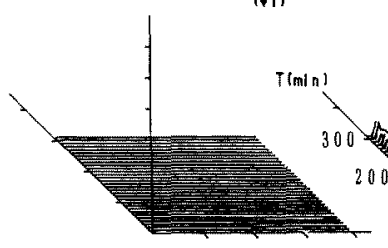

1.4.1

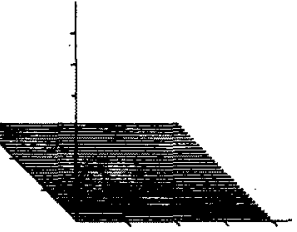

$(+3)$

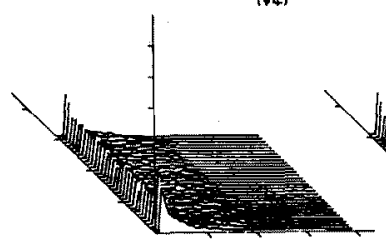

(\$7)
(1)

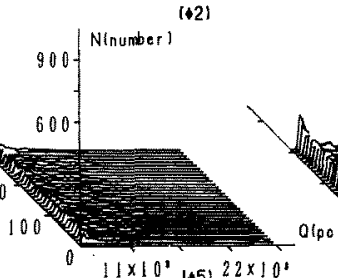

$11 \times 10^{\prime} 441^{2} 2 \times 10^{\prime}$

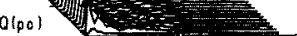

1461

図 4 位相角別放電電荷分布

Fig. 4. Distribution of discharge pulse magnitude at each phase angle window.

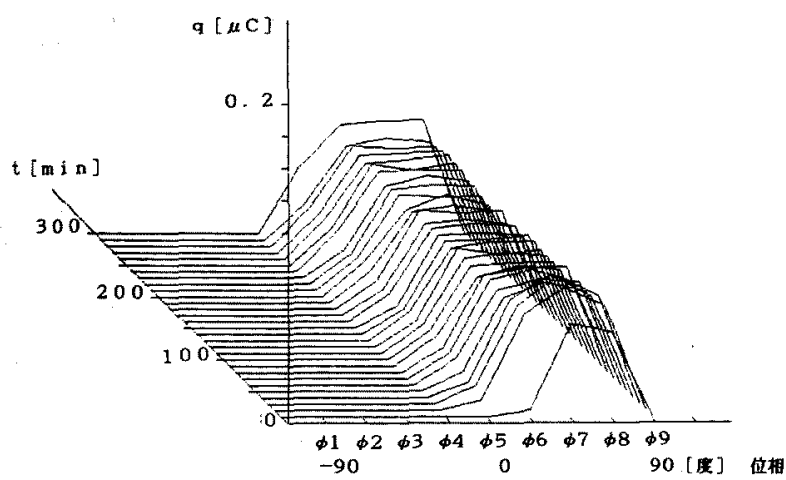

図 5 放電電荷の位相角特性

Fig. 5. Discharge magnitude as a function of phases.
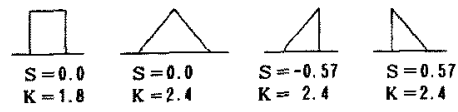

図 6 ひずみ度 $S$, とがり度 $K$ と分布形状

Fig. 6. The skewness and the kurtosis of saveral distributions.

の場合注負の值を，右下がりの場合は正の值となる。 また，とがり度 $K$ は放電の位相的な集中度を表す。

\section{3. 破壊予知のためパラメータ $G, C$ の提案}

本研究では, 放電電荷分布の形状を特徵づけるパラ

電学論A, 110 巻 11 号, 平成 2 年

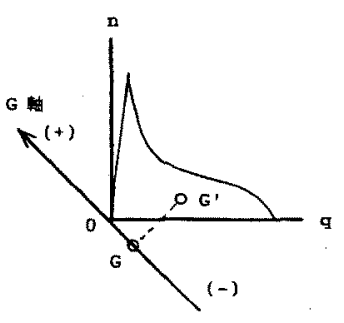

図 $7 G$ 値の定義

Fig. 7. Difinition of $G$-parameter.

\section{位相}

メータとして分布の重心 $G$ 値と傾き $C$ 值を定義し破 壊予知への有効性を検討した。これらのパラメータは 薄手試料ては破壊の前兆現象と考えられる放電の群小 化を象徵し，また見掛けの放電電荷そのものの值を用 いていないことから，他の実験系への適用の可能性が 高いと考えられる。

〈3.1〉Gパラメータ 重心 $G$ の值は図 7 のよ うに, $q-n$ 分布の幾何学的重心 $G$ の座標を求め, そ の挙動を一つの数值で表すため, 原点を通り $45^{\circ}$ 傾い た直線に垂直投影した値を $G$ 值と定義した。これは 放電の群小化が

（i）大きい放電パルスの減少

（ii）小さい放電パルスの増加 

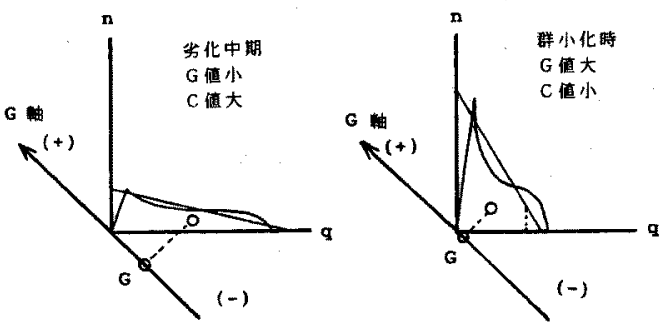

図 8 放電電荷分布形状と $C$ 值, $G$ 值の関係 Fig. 8. Relation between distribution patterns and parameters $C$ and $G$.

が同時に起こることから，450の直線に投影した值が これらの変化を最も感度良く感知すると考えたからで ある。

〈3-2〉 $C$ パラメータ 放電電荷分布のパルス発 生頻度 $n$ を放電電荷 $q$ の関数と考えると

$$
\begin{aligned}
n & =f(q) \\
& =C_{0}+C_{1} q+\cdots+C_{n} q^{n}
\end{aligned}
$$

と表すことができる。ここで $C_{0}, C_{1}, \cdots, C_{n}$ を最小二 乗法で推定する。このとき， $C_{1}$ は近似曲線の傾きを 示す。本論文では $C_{1}$ を傾き $C$ 值として表す。放電の 群小化が起こると $q-n$ 分布は図 8 のように変化し, 分布の傾きは大きくなるが, 負の傾きであるので $C$ 值は減少する。すなわち，本論文でのパラメー夕によ る破壊予知の判断基準は $G$ 值が増加し， $C$ 值が減少 したとき，放電の群小化が起こり破壊の前兆であると 判定することがでる。

\section{4. 結果および検討}

〈4・1〉回帰分析による寿命の推定 本研究では， 得られた実験データ (データ数 40) より, 電圧印加 後 30 分後の放電諸量と絶縁破壊の起こるまでの時間 の関係を回㷌分析により求め, 寿命を推定した。ここ で電压印加後 30 分における放電諸量を用いたのは以 下の理由による。

（1）実験により寿命が異なるが（最短 110 分，最 長 570 分) 破壊を予知するにはできるが゙り早期のほ うが良い。

（2）電圧印加直後は試料の作成状態，気温，湿度 等の諸条件により様々な放電特性を示し，変動が大き いが 30 分でほぼ放電開始後の過渡的状態から定常状 態になる。

まず，放電諸量と寿命の関係を知るため画者の相関 係数を求め，その結果を表1に示す。
表 1 放電諸量と寿命の相関係数

Table 1. Correlation coeficients between time

\begin{tabular}{|c|c|c|c|c|c|c|c|c|c|}
\hline & $Q$ & $N$ & $Q_{A V}$ & $S_{0}$ & $S_{N}$ & $S_{A V}$ & $K_{Q}$ & $K_{N}$ & $K_{A V}$ \\
\hline 寿命 & -0.664 & -0.487 & $-0.032]$ & $|-0.684|$ & -0.684 & -0.126 & 0.593 & 0.600 & 0.483 \\
\hline \multicolumn{10}{|c|}{ 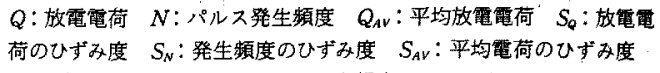 } \\
\hline$K_{Q}:$ 方 & 放電䇥荷 & & & $K_{N}$ : 発 & 生頻度 & のとが & & $\Omega_{A V}$ : 平㙂 & 均電荷 \\
\hline
\end{tabular}
to breakdown and several discharge parameters.

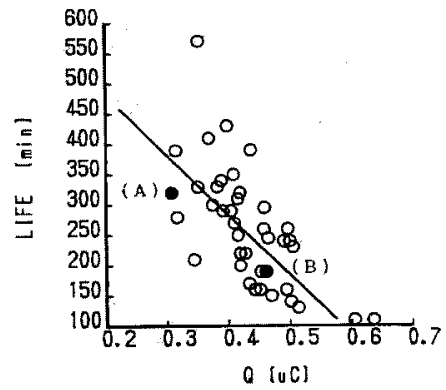

図 9 電圧印加後 30 分の放電電荷と 寿命の相関图

Fig. 9. Correlation map between time to breakdown and dischrge magnitude after $30 \mathrm{~min}$.

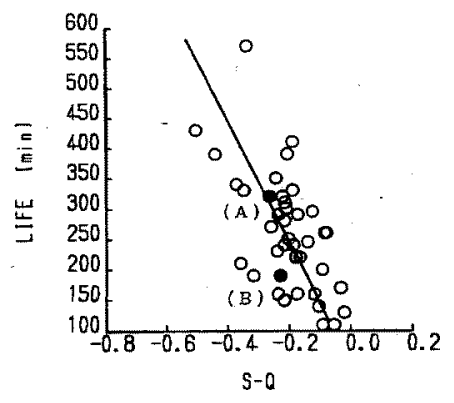

図 10 放電電荷のひずみ度 $S_{Q}$ と 寿命の相関図

Fig. 10. Correlation map between time to braeakdown and skewness of discharge megnitudo.

これより寿命と相関が強いのは放電電荷 $Q$, 放電 電荷のひずみ度 $S_{Q}$, パルス発生頻度のひずみ度 $S_{N}$, 放電電荷のとがり度 $K_{\mathbf{Q}}$, パルス発生頻度のとがり度 $K_{N}$ である。しかも放電電荷 $Q$,ひずみ度 $S_{Q}, S_{N}$ と は負の相関が，とがり度 $K_{Q}, K_{N}$ とは正の相関を示 す。これらの放電諸量と寿命との関係を図 9 図 13 に示す。図 9 は放電電荷が大きいほど寿命が短いこと を示している。ひずみ度 $S$ は図 10, 図 11 のように寿 命と負の相関がある。ここで用いた電極系では位相角 


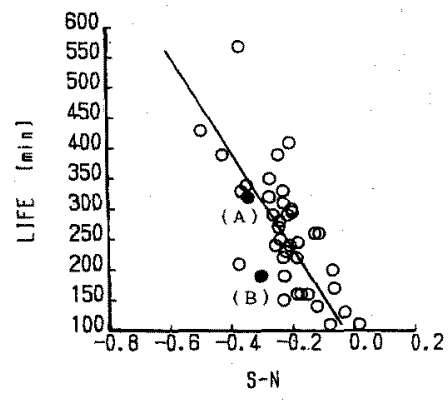

図 11 発生頻度のひずみ度 $S_{N}$ と 寿命の相関図

Fig. 11. Correlation map between time to breakdown the skewness of the pulse number distibution.

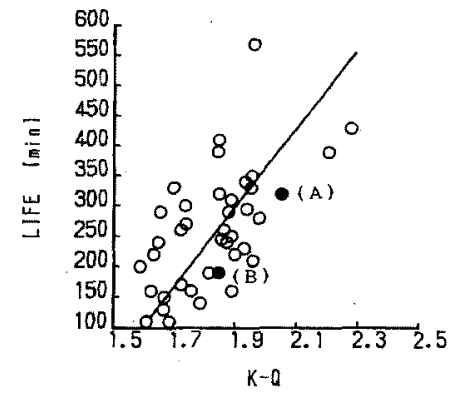

図 12 放電電荷のとがり度 $K_{Q}$ と 寿命相関図

Fig. 12. Correlation map between time to breakdown and the kurtosis of the discharge magnitude distribuon.

特性が右上りの分布形状になるためひずみ度 $S$ は負 の值をとる。よって分布のひずみが大きいほどSの 值は小さくなる。そのため両者の相関は負となってい るが，その意昧は分布のひずみが大きい活ど寿命が長 いことを示している。また図12, 図 13 のようにとが り度 $K$ と寿命との間には正の相関がある。ひずみ度 $S$, とがり度 $K$ の值の変化故電の発生する位相角 の広がりにより大きく影響され， $\phi 5$ で放電が活発に 起こっていない場合はひずみ度，とがり度は大きい。 つまり $\phi 5$ で放電が起こっていない, 放電の発生する 位相角が狭いほど寿命が長いことを示している。そこ でこの五つの放電諸量と寿命の関係から回帰分析より 寿命を推定する。一次回州式を以下に示す。

$$
\begin{aligned}
& L_{1}=663.1-925.7 \times Q \\
& L_{2}=147.9-551.3 \times S_{Q} \\
& L_{3}=122.1-925.7 \times S_{N}
\end{aligned}
$$

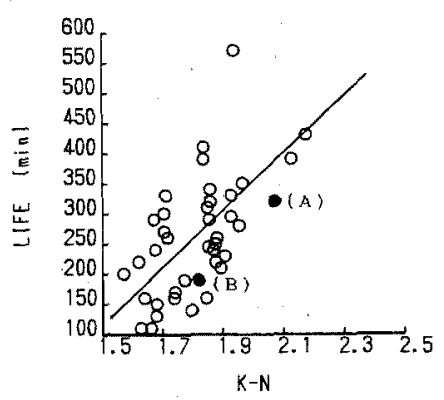

図 13 発生频度のとがり度 $K_{N}$ と 寿命の相関図

Fig. 13. Correlation map between time to breakdown and the kurtosis of the pulse number distribution.

表 2 回㷌分析に上る推定寿命 Table 2. Estimated values of time to breakdown obtained by the regresion analysis.

\begin{tabular}{c|c|c}
\hline & $(A)$ & $(B)$ \\
\hline 寿命 $L$ & 315.0 & 200.0 \\
\hline$Q$ & 371.5 & 232.6 \\
\hline$S_{Q}$ & 302.3 & 296.7 \\
\hline$S_{N}$ & 356.3 & 299.3 \\
\hline$K_{Q}$ & 361.7 & 249.4 \\
\hline$K_{N}$ & 367.6 & 253.0 \\
\hline
\end{tabular}

$$
\begin{aligned}
& L_{4}=-424.5+374.4 \times K_{Q} . \\
& L_{5}=-511.0+424.5 \times K_{N}
\end{aligned}
$$

これらの式により推定した例を表 2 に示す。これらは 実際の寿命が $(A) 315$ 分，抢上び $(B) 200$ 分であった 結果に対する $(2) \sim(6)$ 式による推定值である。同表 より，推定結果はばらつきが比較的大きいため，これ は次節で述べるパラメータによる破塄予知の補助的な 目安にとどめるのが好ましい。しかし，劣化診断を行 う際に，その初期においてある程度の寿命推定を行っ ておくことは有効であり，今後より多くのデー夕を蓄 積することにより推定精度も向上することが期待で きる。

〈4・2〉パラメータによる破壊予知本研究では, 放電電荷分布の形状を特徵づけるパラメータとして分 布の重心 $G$ 值と傾き $C$ 值を定義し破壊予知への有効 性を検討した。これらのパラメー夕は破壊の前兆現象 と考えられる放電の群小化を象徴し，また見掛けの放 電電荷そのものの值を用いていないことから，他の実 験系への適用の可能性が高いと考えられる。パラメー 夕による破壤予知の判断基準は $G$ 值が増加し， $C$ 值 
が減少したとき，放電の群小化が起こり破壊の前兆て あるとする。本研究では，薄手試料であるため，放電 が局所化しトリーが発生すると短時間に破壊に至るも のと考えられ，実験もこのことを支持する結果を示し た。図 14 にC 值, 図 $15 に G$ 值の経時変化を示す。 同図より破壊の直前に $C$ 值が減少し, $G$ 值が増加し ていることがわかり， $C$ 值の減少， $G$ 值の増加によ り破壊予知ができる。このようにC 值，G 值はとも に放電の群小化をとらえるためのパラメータである が， $G$ 值よりも $C$ 值のほうがより群小化を明確に示 す場合が多い。ひずみ度 $S$, とがり度 $K$ は, 厚い試 料に扔けるトリーの発生を検知することを目的として いるが、これらにより破壊予知を行った報告 ${ }^{(6)} あ$

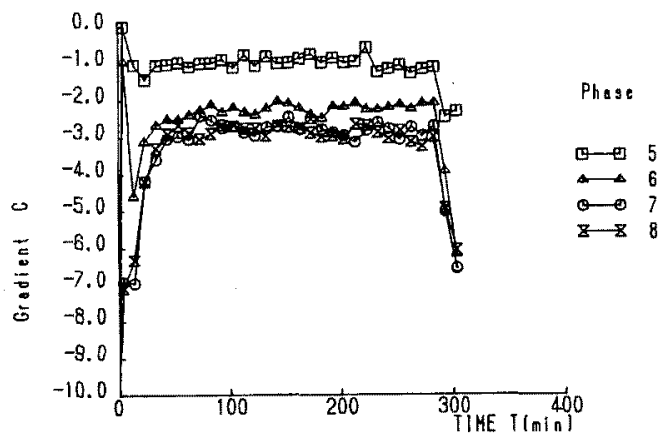

図 $14 C$ 值の経時変化

Fig. 14. $C$-parameter in each phases.

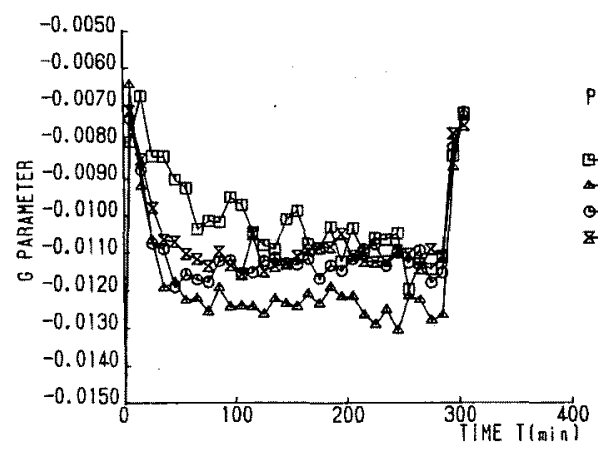

図 $15 G$ 値の経時変化 (a)

Fig. 15. $G$-parameter in each phases.
る。ここで使用した試料のように放電の群小化とトリ 一の発生と破壊が短時間に起こる場合では，破壊直前 であることの予知を行うには，群小化を象徴した $G$ 值， $C$ 值のほうがはっきりとした変化を得ることが できる。図1の電極系における全データ（サンプル数 40）での群小化の確率, および群小化が起こった場合 のこれらのパラメータによる群小化を感知する確率を 表 3 に示す。群小化の起こる確率は 70\%であり，放 電電荷，パルス発生頻度，平均放電電荷の放電諸量に より群小化を感知する確率は $78.6 \%$ ，ひずみ度 $S$, とがり度 $K$ では $39.3 \%, G$ 值，C值では $92.9 \% て$ あり， $G$ 值， $C$ 值が最も感度が良い。実䝷的な破壊 予知確率は群小化の起こる確率に群小化を感知する確 率を乗じたものであり，放電諸量では $55.0 \%$ ，ひず み度 $K$ では $27.5 \% ， G$ 值， $C$ 值で $65.0 \%$ ある。 これらの予知確率は本論文で用いた比較的面積の広い 平行平板状ボイドにおける值であり，ボイド形状，絶 縁厚が変わればこれらの値も変化すると考えられる が，破壊直前に放電の群小化が起これば，いずれかの パラメータにより群小化を感知することができること から, 群小化の起こる確率と破壊の予知確率は同等の ものと考えられる。

しかし，群小化を的確に判定できる $G$ 值， $C$ 值て も破壊予知の確率は $65 \%$ にすぎない。実際に絶縁破 壊事故を末然に防止するという観点からすれば，この 予知確率は十分に高いとは言えない。よって，群小化 の有無が末知の状態でも適用し得る破壊予知法の提案 が要求される。そこで，次に $G$ 値の位相角別の変化 を劣化プロセス全体から見て劣化パターンを分類し， 各々のパターンでの群小化の起こる確率から各々のパ ターンにおける最良の破壊予知法を提案する。劣化パ ターンの分類は фの次数の最も低い位相角, ここで

表 3 各パラメータによる破壊予知確率

Table 3. Probability of prediction of breakdown by the parameter.

\begin{tabular}{|c|c|c|c|c|}
\hline & 放電諸量 & $S, K$ & $G$ 值, $C$ 值 & 総，合 \\
\hline 群小化の起こる確率(\%) & \multicolumn{4}{|c|}{70.0} \\
\hline 群小化を感知する確率（\%) & 78.6 & 39.3 & 92.9 & 100.0 \\
\hline 破壊予知礁率(\%) & 55.0 & 27.5 & 65.0 & 70.0 \\
\hline
\end{tabular}

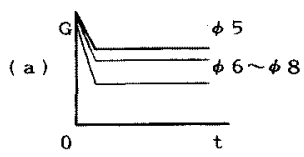

(b)

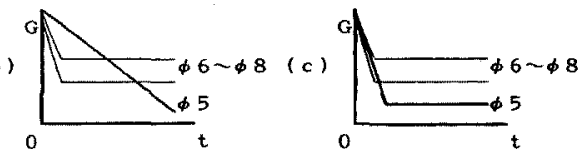

図 $16 G$ 值の変化パターン

Fig. 16. Patterns of changes of $G$-parameter 


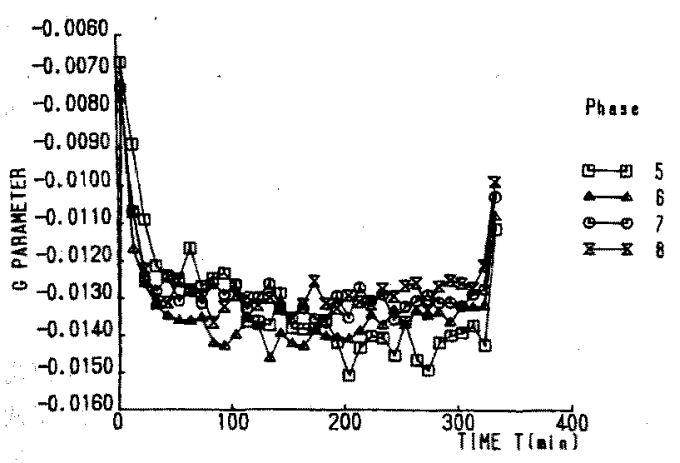

図 $17 G$ 値の経時変化 (b)

Fig. 17. G-parameter (type b).

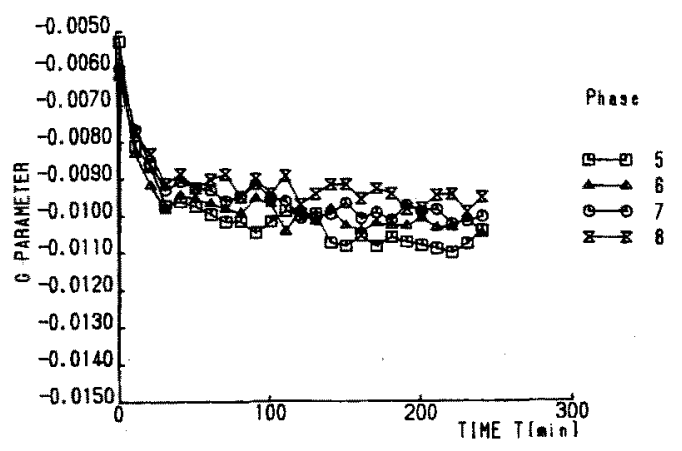

図 $18 G$ 值の経時変化 (c)

Fig. 18. $G$-parameter (type $c$ ).

表 $4 G$ 值に上る劣化パターンの分類 および群小化確率

Table 4. Classification of aging patterns by $G^{-}$ parameter and probability of breakdown.

\begin{tabular}{c|c|c}
\hline & 各劣化パターンの割合 & 群小化の起こる確率 \\
\hline (a) & $32.5 \%(13 / 40)$ & $100.0 \%(13 / 13)$ \\
\hline (b) & $37.5 \%(15 / 40)$ & $60.0 \%(9 / 15)$ \\
\hline (c) & $30.0 \%(12 / 40)$ & $50.0 \%(6 / 12)$ \\
\hline 全 & $100.0 \%(40 / 40)$ & $70.0 \%(28 / 40)$ \\
\hline
\end{tabular}

は $\phi 5$ の $G$ 值の変化に着目して行う。図 16 に $G$ 值の 変化パターンを示す。(a)図は破壊直前まで $\phi 50 G$ 値が他の位相角と比べて，最も大きい値をとる場合で ある。図15はこのバターンに当てはまる。(b)図佶 贫化プロセス全般にわたって $\phi 50 G$ 值が減少し, 忿化中期または後期で最も小さい值になるパターンで ある。図 17 にこのパターンの一例を示す。(c)図は
少化初期に $\phi 50 G$ 值が急激に減少し, 最も小さい 值になり，破壊に至るまでその状態を維持する場合で ある。図18に一例を示す。また，各々のパターンに おける群小化の起こる確率を表 4 に示す（a）図パター ンは全体の $32.5 \%(13 / 40)$ の割合であるが，この場合 梳 100\%群小化が起こる。よって,この場合にG值, $C$ 值で群小化を感知して破壊予知を行えばよい。 (b)図は $37.5 \%(15 / 40)$ の割合であり,この場合群小 化の起こる確率は $60 \%$ であるが，安全性を考えると $\phi 5 の G$ 值が最小になったとき運転を停止することが 必要である。この場合でも劣化末期での判定が行兑 る。また(c)図は $30.0 \%(12 / 40)$ の割合で, 群小化の 起こる確率は $50 \%$ である。この場合は群小化の起こ る確率が低々ので，〈3・1〉節で述べた回䚻分析による 推定寿命を参考にして破壊予知を行うのが好ましい。

\section{5. まとめ}

薄手試料を対象として，ボイド放電出化に扔ける破 壤予知法として出化初期比扔いて放電諸量と寿命の相 関を求め, 回㷌分析汇上り寿命推定を行引方法と, 破

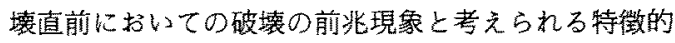
な変化を象徵するパラメータを新たに考案し，それら により破壊予知を行い以下のことを得た。

(1) 少化初期に新ける放電諸量から寿命推定がで きるがその後の劣化過程での劣化形態の変化により 実際の寿命汶異なる場合がある。しかし，劣化初期に 格ける放電電荷分布のパラメー夕の統計回㷌分析によ り寿命の推定を行った。その結果，実寿命の $50 \%$ の 範囲に収まる寿命推定ができた。

(2) 破壊の前兆現象の一つと考六られる放電の群 小化を象徵するパラメータとして放電電荷分布の重心 $G$ 值と傾き $C$ 值を定義し, これらの值の変化により 破壤予知を行った。その結果, 本研究のように薄手試 料でトリーが開始すると，直ちに破壊に至るような場 合は, 約 $93 \%$ 確率で群小化を感知することができ， これらのパラメータは破壞直前での予知に有効である ことが確認できた。

（3）破壞直前に群小伦の起こる確率は70\%であ つた。絶緑破壞の未然防止の観点から群小化の起こら ない場合も考慮にいれて，G值の位相角別の変化に よる破壊予知法を提案した。その際, 劣化初期での寿 命推定が有効になる。

最後に，本研究を遂行するにあたり害駼を手伝って いただいた金田一剛史氏，秋永偷範氏，小山健氏，杉 山裕之氏に感謝いたします。

(平成 2 年 4 月 2 日受付, 同 2 年6 月 1 日再受付) 


\section{文献}

（1）放電専門委員会技術報告, No. 45 (昭 36)

（2）電気学会技報( I 部), No. 74 (昭 41)

(3) 電気学会技報 (II部), No. 164 (昭 59)

(4) 松崎・伊藤, 他：「ポリエチレン内部の円筒状ボイドにおけ る部分放電特性の位相解析」, 電学論 A, 102, 111 (昭 633)

（5）瀬戸・伊藤，他：「針状ボイドにおける放笪笪荷分布の位相 解析」, 同上 A 109,507 (平元-12)

（6）岡本・田中：「部分放電のサイクル平均 $\phi-q$ 特性一 6 種類の 電極形状により実験一」, 電学論 A, 102,381（昭 57-7)

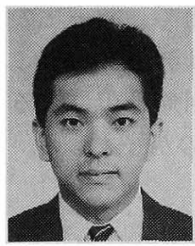

\section{伊 藤 真 澄（正員）}

昭和 39 年 10 月 21 日生。平成 2 年 3 月武蔵工業大学大学院電気工学 専攻修士課程修了。

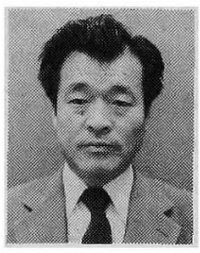

\section{伊 藤 泰 郎 (正員)}

昭和 10 年 9 月 30 日生。 35 年 3 月武蔵工業大学電気工学科卒業。同 年 4 月同大学副手勤, 49 年同助教 授，57 年同教授，現在に至る。工

学博士。 55 年 4 月〜 56 年 4 月アメリカ・クラークソン 工科大学研究員。主として, 高分子絶緑材料の劣化, 放電による気体間反応に関する研究に従事。6 61 年電 気学会論文賞受賞。

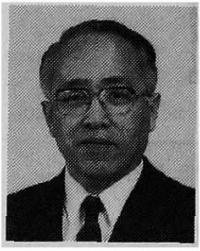

$$
\text { 堺 孝 夫（正員） }
$$

昭和 6 年 6 月 14 日生。 33 年東北 大学大学院修士課程修了。 41 年武 蔵工業大学教授。現在に至る。工学 博士。主として, 高分子材料の伝 導・劣化および沿面放電特性の研究に従事。 42 年イギ リス・サルフォード大学客員研究員。47, 49, 56, 61 年, 電気学会論文賞受賞。応用物理学会, IEEE 会員。

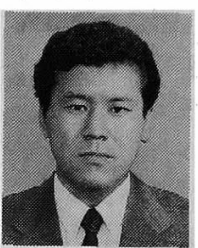

学科勤務。

\section{江 原 由 泰 (非会員)}

昭和 31 年 9 月 22 日生。昭和 54 年 3 月群馬大学工学部合成化学科卒 業。55 年 4 月三恵技研工業(株)入 社。59 年武蔵工業大学電気電子工 